\title{
Procedure to Determine Enzyme Inhibitors Activity in Cereal Seeds
}

\author{
Fernanda Arnhold Pagnussatt ${ }^{1}$, Silvia Letícia Rivero Meza ${ }^{1}$, Jaqueline Garda-Buffon ${ }^{1}$ \& Eliana Badiale-Furlong ${ }^{1}$ \\ ${ }^{1}$ Food Science Laboratory, Chemistry and Food School, Food Science and Engineering Post-Graduation \\ Program, Rio Grande Federal University (FURG), Brazil \\ Correspondence: Fernanda Arnhold Pagnussatt, Food Science Laboratory, Chemistry and Food School, Food \\ Science and Engineering Post-Graduation Program, Rio Grande Federal University (FURG), Brazil. Tel: \\ 55-533-233-8663. E-mail: nandapagnu@terra.com.br
}

\author{
Received: August 27, 2012 Accepted: September 11, 2012 Online Published: November 15, 2012 \\ doi:10.5539/jas.v4n12p85 URL: http://dx.doi.org/10.5539/jas.v4n12p85
}

\begin{abstract}
This work established a procedure for commercial fungal amylase usage as indicator of enzyme inhibitors presence in cereals, intending to screening antifungal resistance properties in cereals. Firstly, the inhibitive effects of oat, wheat and rice protein extracts were assessed against different amylase sources. It was found that the fungal amylase $\left(\right.$ Fungamyl ${ }^{\mathbb{B}}$ ) was the most affected by the inhibition property of the extracts. The best conditions for inhibitor-extract-enzyme interaction were established ( $\mathrm{pH}$, temperature, starch concentration). Inhibition kinetic allowed their classification as mixed inhibitors. A high quocient (1.7) was observed between enzyme inhibition and Fusarium graminearum multiplication reduction. Fungamyl ${ }^{\circledR}$ amylase demonstrated its potential to detect the protein inhibitor presence in different cereals and might be employed in screening natural resistance to fungal contamination.
\end{abstract}

Keywords: commercial enzyme, protein inhibitor, biochemical characterization, fungal multiplication

\section{Introduction}

Alpha-amylase is an endoenzyme that catalyses starch, amylose, amylopectin and glycogen alpha-1.4 bonds hydrolysis. It is produced by several organisms, including fungi, bacteria, plants and animals, allowing both mono and oligossacharides assimilation as an energy sources (Iulek et al., 2000). Amylase inhibitors are abundant in vegetables, tubers and cereals and serve as an efficient defense mechanism against pathogens, such as fungal contamination (Rekha \& Padmaja, 2002). Amylases are commercially available for different purposes, from different sources, such as alpha-amylase, pancreatin, fungal and bacterial. Among them the Fungamyl ${ }^{\circledR}$, alpha-amylase produced by Aspergillus oryzae during fermentation, whose structure is establish in the presence of calcium ions. Temperature and $\mathrm{pH}$ are critical to enzymatic activity, and allow the enzyme utilization in different purposes, that might include as tool for screening the defense mechanism in plants against fungal infection.

Many biotic and abiotic variables affect the plant resistance to fungal contamination. Among the biotic variable the proteinaceous inhibitors of amylases are mentioned as being present in cereal seeds to protect them against this contamination. Identify their presence is interesting to many researches about plant breeder looking for materials with increase resistance to fungi or to establish of storage or process condition in food manufactures, considering the fungal damage or others degradations effects (Valencia-Jimenez, Arboleda, \& Grossi-de-Sá, 2008).

Tests to identify the natural resistance of plants to pathogens and endogenous degradation are lengthy and require physical and chemical determinations in a high number of samples with different locations that constitute the raw material in the food production chain. Rapid tests for identification the lots more susceptible to endogenous or exogenous damage could aid decisions as to handling the grains to use them more efficiently.

Based on these aspects, this work established a procedure for commercial fungal amylase usage as indicator of enzyme inhibitors presence in cereals, intending to screening antifungal resistance properties in cereals. Oat, rice and wheat varieties recommended for cultivation in Rio Grande do Sul were studied about the inhibitory effect of their protein extract. 


\section{Materials and Methods}

\subsection{Samples}

The cultivar BR 424 rice (Oryza sativa L.) sample was supplied by Riograndense Rice Institute (IRGA), cultivar UPFA 22 Temprana oat (Avena sativa L.) by Passo Fundo University and cultivar Safira wheat (Triticum aestivum L.) by Company OR Seeds Improvement. They were ground by knife mill, and then sieved up to a 42 mesh granulometry.

\subsection{Extraction of Protein Inhibitors From Cereals}

The inhibitors were extracted by homogenizing the sample with a $70 \%$ ethanol solvent for oat and wheat, and $95 \%$ ethanol for the rice, at a ratio $1: 5(\mathrm{p} / \mathrm{v})$ for 12 hours. The aliquots from each extraction were homogenized, filtered and the extract was used to test the enzymatic inhibition, conducted in duplicate (Pagnussatt, Bretanha, Garda-Buffon, \& Badiale-Furlong, 2011; Figueira, Hirooka, Mendiola-Olaya, \& Blanco-Labra, 2003). The Lowry method (1951) was used to determine proteins of the extracts, estimating the concentration by a Bovine Serum Albumin standard curve $\left(0.3\right.$ to $\left.2.5 \mathrm{mg} \mathrm{mL}^{-1}\right)$.

\subsection{Specificity of the Protein Inhibitor Extract}

The protein extracts from oat, rice and wheat were tested about their inhibitory effect against the commercial enzymes: amylase from Aspergillus oryzae (Fungamyl ${ }^{\circledR}$ ), supplied by Novozymes, Brazil, containing $0.05 \mathrm{mg}$ protein $\mathrm{mL}^{-1}$; amylase from Bacillus licheniformis (Termamyl ${ }^{\circledR} 120 \mathrm{~L}$ ), supplied by Novo Nordisk, Denmark, containing $0.14 \mathrm{mg}$ protein $\mathrm{mL}^{-1}$; amyloglucosidase from Aspergillus awamori NRLL 3112, supplied by Sigma Aldrich, Brazil, containing $0.13 \mathrm{mg}$ protein $\mathrm{mL}^{-1}$; swine pancreas amylase (pancreatin), supplied by P.A. Nuclear, Brazil, containing $1.23 \mathrm{mg}$ protein $\mathrm{mL}^{-1}$.

The enzymatic inhibition test was performed with $1 \mathrm{~mL}$ of each enzyme solution, $1 \mathrm{~mL}$ of sodium acetate buffer $(0.2 \mathrm{M}) \mathrm{pH} 7.0$ and $0.4 \mathrm{~mL}$ of each protein extract containing the inhibitor (IPE). The protein extracts from oat, rice and wheat contained $0.52 ; 0.60$ and $0.40 \mathrm{mg}$ of protein $\mathrm{ml}^{-1}$, respectively. The mixture was incubated at $25^{\circ} \mathrm{C}$ for 30 minutes, followed by the addition of soluble starch solution $0.5 \%(1 \mathrm{ml})$ and incubated for 30 minutes at the same temperature (Baraj, Garda-Buffon, \& Badiale-Furlong, 2010). In the control experiment, the extracts were substituted by water. The maximum hydrolysis speed of the starch in the control reactors was expressed in $\mu \mathrm{g}$ hydrolyzed starch $\min ^{-1} \mathrm{mg}$ protein ${ }^{-1}$.

One unit of amylolytic activity was defined as the protein mass $(\mathrm{mg})$ required hydrolyzing $0.06 \mathrm{mg}$ starch $\mathrm{min}^{-1}$. One unit of amylase inhibition was defined as the protein mass $(\mathrm{mg})$ required to inhibit one unit of amylase activity in the test conditions (Figueira et al., 2003).

\subsection{Biochemical Characterization of Commercial Fungal Amylase}

The effects of $\mathrm{pH}$, temperature and the stability were evaluated on a commercial fungal amylase solution (1:2000 $\mathrm{v} / \mathrm{v}$ ). The $\mathrm{pH}$ effect was evaluated using buffers $\mathrm{pH} 3-4$ (sodium acetate $0.2 \mathrm{M}$ ), $\mathrm{pH}$ 5-6 (sodium citrate $0.1 \mathrm{M}$ ) and $\mathrm{pH} 7-8$ (tris-HCI $0.2 \mathrm{M}$ ). It was observed the same procedure as described item 2.3.

Enzyme stability at the $\mathrm{pH}$ was carry out by $30,60,90,120,180,240$ and 300 minutes at $25^{\circ} \mathrm{C}$ before adding the starch solution. The effect of the temperature was investigated by incubating the reaction mixture containing buffer $\mathrm{pH} 5$, at temperatures of $25^{\circ} \mathrm{C}, 35^{\circ} \mathrm{C}, 45^{\circ} \mathrm{C}$ and $60^{\circ} \mathrm{C}$ for 30 minutes. Thermal stability was assessed at the same temperatures, with prior incubation of the enzymatic solution in buffer for 30,60 and 90 minutes before the addition of substrate for evaluating enzymatic activity (Baraj, Garda-Buffon, \& Badiale-Furlong, 2010).

After the establishment of the best condition for $\mathrm{pH}$ and temperature, the enzymatic reaction was evaluated about substrate concentration with and without the IPE. The substrate concentrations were $2.5 ; 5 ; 7.5$ and $10 \mathrm{mg} \mathrm{ml}^{-1}$ and the enzyme solution contained $0.05 \mathrm{mg} \mathrm{m}^{-1}$. The inhibitors were added at concentration described below, to identifying the kinetic enzyme parameter in absent and presence of the protein cereal extracts:

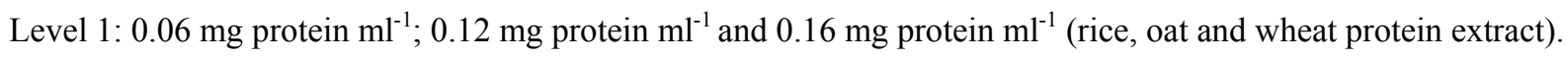

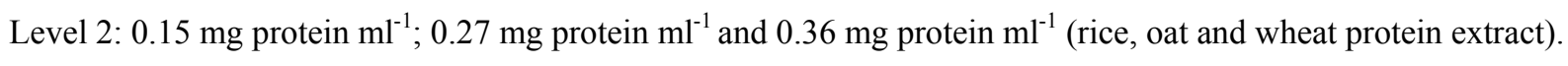

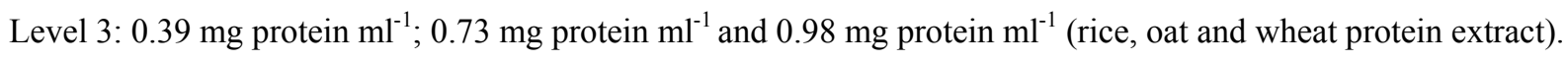

\subsection{Characterization of Protein Extracts with Inhibitory Activity (IPE)}

The stability of the IPEs was tested by monitoring the inhibitory effect after storage at $-5^{\circ} \mathrm{C}$ for a 60 -day period, as per described in item 2.1. The water activity effect on the inhibitory action of the protein extracts was evaluated by soaking the entire grains with moisture levels of $20 \%, 50 \%$ and $80 \%$ in a germination chamber at $25^{\circ} \mathrm{C}$. The 
quantity of water added (M) was established considering the initial moisture content of each cereal and final desired moisture content, according to Equation 1:

$$
(100 \text { - initial moisture content }) \times 100=\mathrm{M} \text { x }(100 \text { - desided moisture content })
$$

At intervals of $0,1,2,4$ and 8 days, samples were dried in a convection oven at $50^{\circ} \mathrm{C}$ and ground in a knife mill to a particle size of 32 mesh for the inhibitory activity evaluation against commercial fungal amylase (Fungamyl ${ }^{\circledR}$ ).

The effect of the temperature on the inhibitory capacity of the extracts was assessed following heat treatment at $25^{\circ} \mathrm{C}, 35^{\circ} \mathrm{C}, 45^{\circ} \mathrm{C}$ and $60^{\circ} \mathrm{C}$, followed by incubation of the extract and Fungamyl ${ }^{\circledR}$ enzyme mixture at its optimum $\mathrm{pH}$. The effect of the $\mathrm{pH}$ on the protein extracts and their inhibitory capacity was determined by incubating the enzyme and the inhibitor in the following buffers: sodium acetate $(\mathrm{pH} 3$ and 4), sodium citrate (pH 5 and 6 ) and tris- $\mathrm{HCl}(\mathrm{pH} 7$ and 8). The stability of the inhibitor during incubation time was determined by using $1 \mathrm{~mL}$ of the protein extract previously incubated in a thermostatic bath at a temperature of $25^{\circ} \mathrm{C}$ and $\mathrm{pH} 5$ (optimum conditions for enzymatic action), with samples collected at intervals of 30, 60,120, 180, 240 and 300 minutes, for activity measurement. The stability of the enzyme inhibitor at different $\mathrm{pH}$ values was assessed, with the protein extract being incubated in buffers with $\mathrm{pH}$ varying from 3 to 8 , at $25^{\circ} \mathrm{C}$, for 30 minutes. In all cases, the inhibitory activity was estimated as per described in item 2.1.

The inhibition percent (IE\%) of the enzymatic reaction was estimated based on the ratio between the maximum speed and the speed of the inhibited reaction, as per Equation 2.

$$
100 \text { - \% I (specific speed at inhibitor presence/specific speed at inhibitor absence) x } 100
$$

The results of the inhibitions provoked in the enzyme by the protein extracts were statistically evaluated through analysis of variance (ANOVA) and the Tukey test $(\mathrm{p}<0.05)$.

\subsection{Antifungal Effect of the Inhibitory Extracts}

The culture medium (potato dextrose agar-PDA) was autoclaved during 15 minutes at $121^{\circ} \mathrm{C}$ with subsequent inhibitory extracts addition ( $40 \mathrm{mg}$ protein $30 \mathrm{ml}-1$ PDA). The Petri dishes containing the mixture were prepared under aseptic conditions (Laminar Flow Chamber Labconco model 36 210, type B2), on the control plates the same amounts of sterile water were added, instead of the protein solution. The plates were inoculated with $4 \times 106$ spores Fusarium graminearum CQ244, incubated in a germination chamber (model Tecnal TE-403), at $30^{\circ} \mathrm{C}$ and relative humidity $40 \%$ on the 5 th, 14 th and 21 st days.

The antifungal activity was evaluated by the glucosamine content determination in the culture (Nguefack et al. 2004). The percentage of fungal inhibition was calculated according to Equation 3.

$$
\text { Inhibition }=100 \times((\text { control-treatment }) / \text { control }) \text {. }
$$

\subsection{Statistical Analysis}

The data generated from this study were subjected to one-way analysis of variance (ANOVA) at $5 \%$ level of significance. Means were compared by Tukey test. All determinations were carried out in triplicates.

\section{Results and Discussion}

\subsection{Specificity of the Protein Extracts}

The wide distribution of amylases in living being results in their different metabolic control mechanisms, such as the presence of protein inhibitors, abundant in grains and cereals (Figueira et al., 2003) where they also exert the function of defending against pathogenic attacks. Protein compounds with inhibition activity are found in the prolamin fraction and can be recovered from the source with alcohol solutions. Considering these properties the enzyme inhibitors were extracted from the cereals under study (Pagnussatt et al., 2011).

First it was evaluated the commercial amylases that was more susceptible to the protein inhibitors extracts from the seed comparing them by the specific inhibition percentage affected was the amylase from Aspergillus oryzae, marketed as Fungamyl ${ }^{\circledR}$, with specific inhibition $50 \%, 43 \%$ and $67 \%$, respectively, by rice, oat and wheat extracts (Table 1).

When comparing the enzymes susceptibility from different sources, such as amyloglucosidase, also obtained from a fungus belongs to the Aspergillus genus and amylase from bacteria (Termamyl ${ }^{\mathbb{B}}$ ), the inhibition values of Fungamyl ${ }^{\circledR}$ proved to be statistically superior, suggesting that the cereal seeds might be better protect against the genus Aspergillus attack. Table 1 demonstrated the amylases inhibition percent by the IPEs. 
Table 1. Effect of the proteic extract against amylases from different sources

\begin{tabular}{llll}
\hline Enzyme & Rice inhibitor $^{1,2}$ & Oat inhibitor $^{1,2}$ & Wheat inhibitor $^{1,2}$ \\
\hline Fungamyl & $50 \pm 5.1^{\mathrm{a}}$ & $43 \pm 0.1^{\mathrm{A}}$ & $67 \pm 0.6^{1}$ \\
Amyloglucosidase & $20 \pm 1.6^{\mathrm{b}}$ & $24 \pm 0.4^{\mathrm{C}}$ & $7 \pm 0.3^{2}$ \\
Termamyl & $19 \pm 1.3^{\mathrm{b}}$ & $28 \pm 0.2^{\mathrm{B}}$ & $5 \pm 0.1^{3}$ \\
Pancreatin & $7,3 \pm 0.2^{\mathrm{c}}$ & $19 \pm 0.4^{\mathrm{D}}$ & $6 \pm 0.4^{2,3}$ \\
\hline
\end{tabular}

${ }^{1}$ Mean \pm standard deviation. Means followed by different letters present relevant difference through the Tukey Test at a relevant level of $0.05 .{ }^{2}$ Results expressed in inhibition percent.

This behavior is determined by the sequence of amino acids and structure of both the enzyme and inhibitor; which may also have occurred in this study, showing that Fungamyl ${ }^{\circledR}$ could be used as an indicator of enzyme inhibitor presence to track different stages of the study about cereal resistance against fungal attack.

The specificity of inhibitors obtained from rye was also tested by Iulek, Franco, Silva, Slivinski, Block, Ridgen and Grossi-de-Sá (2000) against enzymes from human saliva and extracted from insects, among others, and in these experiments the interest was enzymes from microorganisms that may grow on cereals.

\subsection{Control Parameters of Fungal Amylase Activity}

When an enzyme is employed for any purpose, knowing the factors that affect its activity is of fundamental importance (Campbell \& Farrel, 2007), in special in this case which the interest is evaluating the inhibition effects of the protein extracts. Therefore, Fungamyl ${ }^{\circledR}$ was characterized in terms of $\mathrm{pH}$ and temperature effects on its activity and stability too.

In sodium citrate buffer $(0.1 \mathrm{M}) \mathrm{pH} 5$ and temperature of $25^{\circ} \mathrm{C}$, the ideal complex of fungal amylase was formed with the substrate, which specific activity $\left(10 \mu \mathrm{g}\right.$ hydrolyzed starch $\mathrm{min}^{-1} \mathrm{mg}$ protein $\left.{ }^{-1}\right)$ stays stable for 180 minutes. Amylases from other fungal source are being demonstrated less thermal stability (Frolova, Sil'Chenko, Pivkin, \& Mikhailov, 2002) or as amylase from F. moniliforme that as thermo stable as Fungamyl ${ }^{\mathbb{B}}$ at $\mathrm{pH} 6.5$ (Figueira et al., 2003).

\subsection{Protein Extracts with Inhibitory Activity Properties (IPE)}

Studies that report amylase inhibitor stability through cold storage are scarce; however, this lends significant support when the intention is to isolate and identify the inhibitor structure, use it in a raw form to inhibit fungal growth, hence that was done in this work, or over to estimate the susceptibility to the condition of food storage or process.

The results obtained for the protein extracts from Onix wheat stood out, as the inhibitory capacity was maintained throughout the experiment interval at $-5^{\circ} \mathrm{C}$, with an average value around $50 \%$. The UPFA 22 Temprana oat extracts showed an $11 \%$ reduction in enzymatic activity over the course of the storage period, and for the BR 424 rice protein extract, the decline in activity began on the $5^{\text {th }}$ day and remained stable until the $15^{\text {th }}$ day. This information might be important when one need to establish storage condition to the cereals.

The inhibition percent caused by the rice protein extract was greatest at time zero in all the waterlogged conditions, and reduced over the course of time, indicating that the water activity $\left(\mathrm{a}_{\mathrm{w}}\right)$ reduces inhibitor efficiency, demonstrating the fragility of the defense mechanisms of the grain during its formation or inadequate storage (Figure 1). This risk was demonstrated when the grain was stored at $80 \%$ relative humidity, where the extract containing the inhibitor reduced the enzymatic speed by $26 \%$ on the eighth day of the experiment. The inhibitory behavior of the protein extracts from the wheat was similar to the rice one, seeing as the greater the $\mathrm{a}_{\mathrm{w}}$, the lower the inhibitory capacity. Out of all the cereals, oat presented the protein extracts more efficient as inhibition maintaining under any condition studied, at an inhibition capacity around $65 \%$ after 8 days.

It is worth remembering that during the germination of monocotyledon seeds, such as cereals, the gibberellins present in the scutellum move to the aleurone, the superficial layer of the endosperm and promote synthesis of hydrolytic enzymes, including amylases (Bogatek, Gniazdowska, Zakrzewska, Oracz, \& Gawroński, 2006). The process is driven by balancing between the content levels of active promoters and inhibitors, starting with the stimulation of the promoter, which reduces enzyme inhibitor activity. Based on this mechanism, the germination process likely results from lack of inhibitor activity and in consequence increasing the susceptibility to fungal attack (Kadozawa, Figueira, \& Hirooka, 2002). This fact, as well as other evidence, demonstrates that during an 
increased storage period, the grains also might became more susceptible to fungal contamination, as consequence of the reduced inhibitors activity; shown here by the reduced inhibition on Fungamyl ${ }^{\mathbb{B}}$ activity along the experiments.

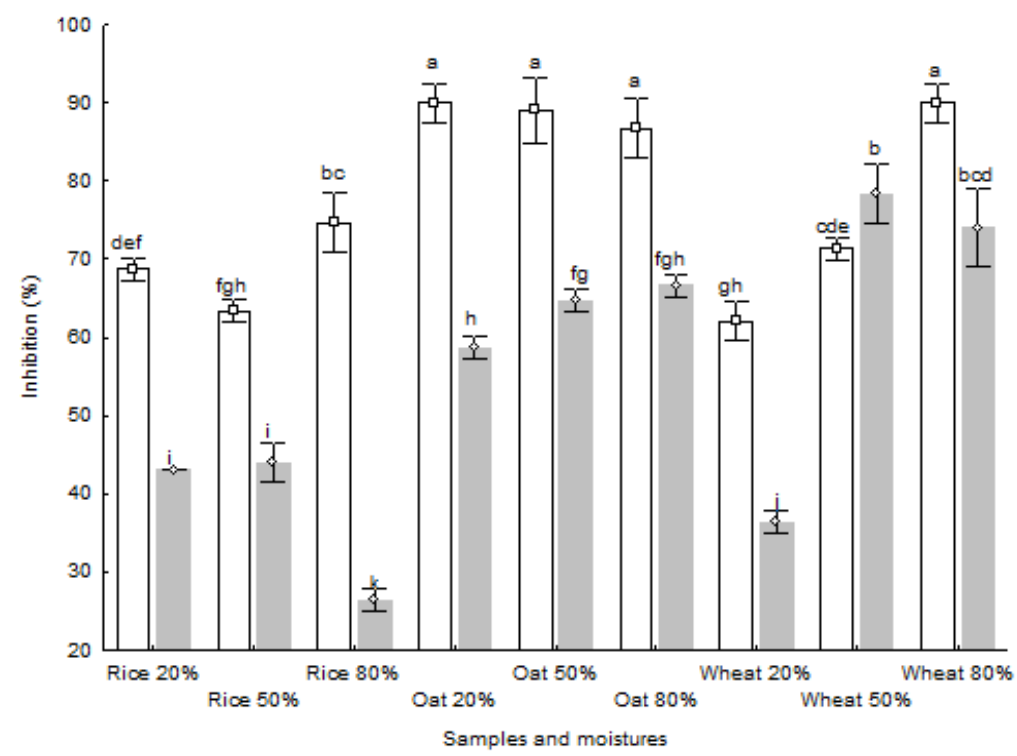

Figure 1. Inhibition percent (\%) of Fungamyl ${ }^{\circledR}$ by proteic extracts from grains with different moisture content. Mean \pm standard deviation. Means followed by different letters present relevant difference through the Tukey Test at a relevant level of 0.05 . Results expressed in inhibition percent. Zero day $(\square), 8^{\text {th }}$ day $(\square)$

The water activity did not affect the inhibitors obtained from oat, suggesting that these are more resistant against environmental variations and possibly being the grain less susceptible to microbial contamination, although other abiotic variable, such as chemical composition, may also influence this response. This possibility was investigated with xylanase and it demonstrated that it was inactivated during the wheat germination when the grain appeared more susceptible Aspergillus niger contamination (Elliot, MCClauchlan, Williamson, \& Kroon, 2003).

The $\mathrm{pH}$ near to neutral or slightly acidic provided the most favorable conditions for inhibitory activity on the enzyme (Table 2), similar behavior to that found by other experiments with commercial alpha-amylase before (Gibbs \& Ali, 1998).

Table 2. Effect of the EPI in the amylase specific activity ( $\mu \mathrm{g}$ hydrolyzed starch $\min ^{-1} \mathrm{mg}$ protein ${ }^{-1}$ )

\begin{tabular}{|c|c|c|c|c|}
\hline Buffer & $\begin{array}{l}\text { Fungamyl }{ }^{82]} \\
\text { (control) }\end{array}$ & Rice inhibitor $^{1}$ & Oat inhibitor $^{1}$ & Wheat inhibitor $^{1}$ \\
\hline Acetate $\mathrm{pH} 3$ & $8.0^{\mathrm{a}, \mathrm{b}}$ & $6.6 \pm 0.05^{\mathrm{b}, \mathrm{c}}$ & $3.0 \pm 0.05^{\mathrm{F}}$ & $7.6 \pm 0.00^{5}$ \\
\hline Acetate $\mathrm{pH} 4$ & $7.4^{\mathrm{a}, \mathrm{b}}$ & $6.6 \pm 0.03^{\mathrm{b}, \mathrm{c}}$ & $3.7 \pm 0.01^{\mathrm{E}}$ & $7.9 \pm 0.09^{2,3}$ \\
\hline Citrate $\mathrm{pH} 5$ & $10.2^{\mathrm{a}}$ & $6.5 \pm 0.00^{\mathrm{c}}$ & $4.6 \pm 0.03^{C}$ & $8.3 \pm 0.09^{2}$ \\
\hline Citrate pH 6 & $7.3^{\mathrm{a}, \mathrm{b}}$ & $7.4 \pm 0.07^{\mathrm{b}}$ & $4.8 \pm 0.00^{\mathrm{B}}$ & $9.6 \pm 0.00^{1}$ \\
\hline Tris- $\mathrm{HCl} \mathrm{pH} 7$ & $7.3^{\mathrm{a}, \mathrm{b}}$ & $8.7 \pm 0.05^{\mathrm{a}}$ & $5.0 \pm 0.01^{\mathrm{A}}$ & $7.4 \pm 0.03^{3}$ \\
\hline Tris- $\mathrm{HCl} \mathrm{pH} 8$ & $6.7^{\mathrm{b}}$ & $7.1 \pm 0.01^{\mathrm{b}, \mathrm{c}}$ & $3.4 \pm 0.00^{\mathrm{\nu}}$ & $5.7 \pm 0.06^{4}$ \\
\hline \multicolumn{5}{|c|}{ Temperature $\left({ }^{\circ} \mathrm{C}\right)$} \\
\hline 25 & $2.9^{\mathrm{a}}$ & $0.68 \pm 0.09^{\mathrm{a}}$ & $5.80 \pm 0.162^{A}$ & $16.57 \pm 0.15^{1}$ \\
\hline 35 & $2.9^{\mathrm{a}}$ & $0.42 \pm 0.29 b$ & $3.42 \pm 2.42^{\mathrm{B}}$ & $16.56 \pm 0.076^{1}$ \\
\hline 45 & $2.5^{\mathrm{b}}$ & $0.36 \pm 0.25 c$ & $4.10 \pm 1.07^{\mathrm{B}}$ & $12.55 \pm 0.18^{2}$ \\
\hline 60 & $0.3^{\mathrm{c}}$ & $0.42 \pm 0.31 b$ & $3.11 \pm 1.80^{c}$ & $1.17 \pm 0.06^{5}$ \\
\hline
\end{tabular}

${ }^{1}$ Mean \pm standard deviation. Means followed by different letters present relevant difference through the Tukey Test at a relevant level of 0.05 . Results expressed in $\mu \mathrm{g}$ hydrolyzed starch $\mathrm{min}^{-1} \mathrm{mg}$ protein ${ }^{-1}$. 
Enzyme inhibitors in cereals are composed of 2 or 4 polypeptide chains wich dissociate with the initial temperature, losing their effect on the amylase (Lajolo \& Finardi, 1995). In these experiments, the optimum temperature for the extracts action on fungal amylase inhibition varied from $25^{\circ} \mathrm{C}$ to $60^{\circ} \mathrm{C}$. The specific activity of all the inhibitors at $25^{\circ} \mathrm{C}$ was statistically superior to the others conditions (Table 2), underlining the fact that, proteins are constituted by polypeptide chains highly susceptible to the effect of the initial temperature, demonstrated by the reduced inhibition with each $10^{\circ} \mathrm{C}$ temperature increase. The wheat protein extract was the least stable to the temperature effect, as after one hour of heat treatment, its specific inhibitory activity had diminished by $40 \%$.

At the optimum temperature and $\mathrm{pH}$ levels for action, all the protein extracts maintained maximum activity for 30 minutes at $25^{\circ} \mathrm{C}$, followed by a fall at 120 minutes and at 180 minutes, corresponding approximately to a $75 \%$ reduction. The inhibitor extracted from oat presented the least specific activity throughout the incubation period in relation to the others.

Different kinds of inhibition behavior have been reported depending on the sources, as well as the kind of amylase (Figueira et al., 2003), lending weight to the argument that inhibition is a specific mechanism to each species, as a response to the risk to which they are subjected during their evolution. The varieties studied are made this clear against the amylase activity as an indicator.

The results described here indicate that Fungamyl ${ }^{\circledR}$ is also suitable for assessing the efficiency of the inhibitory potential in virtue of the $\mathrm{pH}$, temperature and enzyme-inhibitor interaction time, and may be used to evaluate the susceptibility of the grains and their byproducts along the various conditions during their cultivation, beneficiation and storage.

The substrate concentration effect was observed in presence and absent of the extracts. Considering that the enzymes had high purity to food degree, the speed of the starch hydrolysis was carry out by the Michaelis-Mentem kinetics behavior, using Lineweaver-Burk double reciprocal plots to intent identifying the type of inhibition caused. The inhibition constant value $\left(\mathrm{K}_{\mathrm{I}}\right)$ and the maximum speed $\left(\mathrm{V}_{\mathrm{max}}\right)$ are estimated (Table 3$)$.

The effects of the protein extracts (IPE) from rice demonstrated that uncompetitive inhibition of amylase occurred with lower concentrations of IPE; whereas with higher levels, the $\mathrm{V}_{\max }$ reduced and the $\mathrm{K}_{\mathrm{I}}$ increased, characteristic of mixed inhibition (Campbell \& Farrell, 2007). The increased concentration of extract containing fungal amylase inhibitor produced greater affinity between the inhibitor and enzyme, which fact could be observed through the reduced $\mathrm{K}_{\mathrm{m}}$ value.

Table 3. $\mathrm{K}_{\mathrm{m}}$ and $\mathrm{V}_{\max }$ in presence and absence of the inhibitors extracts

\begin{tabular}{cccc}
\hline Reaction & Protein $\left(\mathrm{mg} \mathrm{mL}^{-1}\right)$ & $\mathrm{K}_{\mathrm{m}}$ & $\mathrm{V}_{\max }$ \\
\hline Control & - & 0.0069 & 0.0200 \\
\hline \multirow{3}{*}{ Rice inhibitor } & & $\mathrm{K}_{\mathrm{I}}$ & $\mathrm{V}_{\operatorname{maxI}}$ \\
& 0.06 & 0.6375 & 0.6389 \\
& 0.15 & 0.0004 & 0.0130 \\
Oat inhibitor & 0.39 & 0.0120 & 0.0084 \\
\hline \multirow{3}{*}{ Wheat inhibitor } & 0.12 & 0.0023 & 0.0034 \\
& 0.27 & 0.0210 & 0.013 \\
& 0.73 & 0.0556 & 0.2012 \\
\hline
\end{tabular}

All the IPEs presented a similar behavior model, which also suggests that other compounds in the extracts might contribute to the reduced the starch hydrolyse speed. Gibbs and Alli (1998) found classic competitive inhibition in beans against commercial amylase.

The lowest $\mathrm{K}_{\mathrm{I}}$ value was found with wheat protein extract, reflecting the high affinity of the catalytic site of the bond (enzyme) to recognize and connect to the inhibitors. These results also indicate that the complex formed between the wheat inhibitor, commercial fungal amylase and starch was more stable than that with oat and rice. 
Such behavior allowed classification of the inhibition kinetics caused by the inhibitor extracts as mixed, also suggesting that the compounds structure responsible for the inhibition might be associated to the enzyme in various situations, still unexplained.

In terms of the cereal defense, this fact is of utmost importance, as the amylase investigated may be used to indicate the presence of proteins with antifungal activity too, covering a broad range of risk.

\subsection{Antifungal Activity of the Extracts}

Bearing in mind the interest in obtaining and purifying these enzyme inhibitors for application as natural anti-fungicides, the rice, oat and wheat protein extracts were tested for their inhibitory power against the multiplication of a species of Fusarium graminearum too once the results suggest that the inhibitors might be very efficient against the Aspergillus genus.

Multiplication of the aforementioned microorganism, evaluated as glucosamine content, showed that the extract inhibit it until $75 \%, 91 \%$ and $86 \%$ by rice, oat and wheat extracts, respectively, over the course of 21 days.

In all the raw extracts, the inhibition of Fusarium graminearum was greater than that against the activity of the amylase from Aspergillus flavus. This relation indicated that the inhibition of microorganism multiplication used in this study can be occurred through in a similar mechanisms to those verified studding the commercial fungal amylase. Therefore, determining inhibition with commercial enzyme is an interesting tool in the grain resistance assessment against attacks by phytopathogenic microorganisms, as well as supporting the quick identification of the inhibition properties in different natural sources. This information is important to decide about storage and processing condition along the agro industrial cereal chain too.

\section{Conclusion}

The fungal amylase Fungamy ${ }^{\circledR}$ is susceptible to alcoholic protein extracts from oat, rice and wheat. The protein extracts containing enzyme inhibitors demonstrated distinct inhibition behavior patterns, but all of them inhibited fungal amylase. The specific inhibition of commercial amylase (Fungamyl ${ }^{\circledR}$ ) and the inhibition of the Fusarium graminearum development in the culture by the extracts reinforce the possibility to employ the enzyme amylase as indicator of the cereal susceptibility to fungal contamination.

\section{Acknowledgments}

The authors are grateful to the Novozymes ${ }^{\circledR}$, IRGA, UPF and OR Melhoramento de Sementes for material support.

\section{References}

Baraj, E., Garda-Buffon J., \& Badiale-Furlong, E. (2010). Effect of Deoxynivalenol and T-e Toxin in Malt Amylase Activity. Brazilian Archives of Biology and Tecnology, 53(3), 505-511. http://dx.doi.org/10.1590/S1516-89132010000300002

Bogatek, R., Gniazdowska, A., Zakrzewska, W., Oracz, K., \& Gawroński, S. W. (2006). Allelopathic effects of sunflower extracts on mustard seed germination and seedling growth. Biologia Plantarum, 50, 56-158. http://dx.doi.org/10.1007/s10535-005-0094-6

Campbell, M. K., \& Farrell, S. O. (2007). Bioquímica. São Paulo: Editora Thompson Learning.

Elliott, G. O., MClauchlan, W. R., Williamson, G., \& Kroon, P. A. (2003). A wheat xylanase inhibitor protein (XIP-I) accumulates in the grain and has homologues in other cereals. Journal of Cereal Science, 37(2), 187-194; 2003. http://dx.doi.org/10.1006/jcrs.2002.0493.

Figueira, E. L. Z., Hirooka, E. Y., Mendiola-Olaya, E., \& Blanco-Labra, A. (2003). Characterization of a Hydrophobic Amylase Inhibitor from Corn (Zea mays) Seeds with Activity Against Amylase from Fusarium $\begin{array}{lllll}\text { verticillioides. Biochemistry and Cell Biology, 93, 8, 917-922. } & \text {. }\end{array}$ http://dx.doi.org/10.1094/PHYTO.2003.93.8.917.

Frolova, G. M., Sil'Chenko, A. S., Pivkin, M. V., \& Mikhailov, V. V. (2002). Amylases of the Fungus Aspergillus flavipes Associated with Fucus evanescens. Applied Biochemistry and Microbiology, 38, 2, 134-138. http://dx.doi.org/10.1023/A:1014354431672.

Gibbs, B. F., \& Alli, F. (1998). Characterization of a purifed $\alpha$-amylase inhibitor from white kidney beans (Phaseolus vulgaris). Food Research International, 31, 3, 217-225. http://dx.doi.org/10.1016/S0963-9969(98)00074-X 
Iulek, J., Franco, O. L., Silva, M., Slivinski, C. T., Block, Jr., C., Rigden, D. J., \& Grossi-de-Sá, M. F. (2000). Purification, biochemical characterization and partial primary structure of a new a-amylase inhibitor from Secale cereale (rye). International Journal of Biochemical and Cell Biology, 32, 1195-1204.

Kadozawa, P., Figueira, E. L. Z., \& Hirooka, E.Y. (2002). Inibidores de enzimas contra Fusarium moniliforme durante a germinação de milho. Semina: Ciências Agrárias, 23(2), 249-258.

Lajolo, F. M., \& Finardi-Filho, F. (1984). Purificação do inibidor de alfa-amilase do feijão preto (Phaseolus vulgaris) var. Rico 23. Ciência e Tecnologia de Alimentos, 4, 1-11.

Lowry, O. H. (1951). Protein measurement with the folin-phenol reagent. Journal of Biological Chemistry, 193, 265-275.

Pagnussatt, F. A., Bretanha, C. C., Garda-Buffon, J., \& Badiale-Furlong, E. (2011). Extraction of fungal amylase inhibitors from cereal using response surface methodology. International Research Journal of Agricultural Science and Soil Science, 1, 428-434.

Rekha, M. R., \& Padmaja, G. (2002). Alpha-amylase inhibitor changes during processing of sweet potato and taro tubers. Plant Foods for Human Nutrition, 57, 285-294.

Valencia-Jiménez, A., Arboleda, J. W. A., \& Grossi-de-Sá, M. F. (2008). Activity of $\alpha$-amylase inhibitors from Phaseolus coccineus on digestive $\alpha$-amylase of the coffee berry borer. Journal of Agricultural and Food Chemistry, 56, 2315-2320. http://dx.doi.org/10.1021/jf0733564. 